\title{
Antifungal screening and in silico mechanistic studies of an in-house azole library
}

\author{
Suat Sari ${ }^{a} *$, Didem Kart ${ }^{b}$, Suna Sabuncuoğlu ${ }^{c}$, İnci Selin Doğan ${ }^{d}$, Zeynep Özdemir ${ }^{\mathrm{e}}$, İrem \\ Bozbey ${ }^{\mathrm{e}}$, Melis Gencel ${ }^{f}$, Şebnem Eşsiz ${ }^{f}$, Jóhannes Reynisson ${ }^{\mathrm{g}, \mathrm{h}}$, Arzu Karakurt ${ }^{\mathrm{e}}$, Selma Saraç ${ }^{\mathrm{a}}$, \\ Sevim Dalkara ${ }^{\mathrm{a}}$
}

${ }^{a}$ Hacettepe University, Faculty of Pharmacy, Department of Pharmaceutical Chemistry, 06100, Ankara, Turkey

${ }^{\mathrm{b}}$ Hacettepe University, Faculty of Pharmacy, Department of Pharmaceutical Microbiology, 06100, Ankara, Turkey

' Hacettepe University, Faculty of Pharmacy, Department of Pharmaceutical Toxicology, 06100, Ankara, Turkey

${ }^{d}$ Karadeniz Technical University, Faculty of Pharmacy, Department of Pharmaceutical Chemistry, 61080, Trabzon, Turkey

e Inönü University, Faculty of Pharmacy, Department of Pharmaceutical Chemistry, 44280, Malatya, Turkey ${ }^{\mathrm{f}}$ Kadir Has University, Faculty of Engineering and Natural Sciences, Department of Bioinformatics and Genetics, 34083, Istanbul, Turkey

${ }^{\mathrm{g}}$ The University of Auckland, School of Chemical Sciences, 23 Symonds Street, 1142 Auckland, New Zealand ${ }^{\mathrm{h}}$ School of Pharmacy, Keele University, Hornbeam Building, Staffordshire ST5 5BG, United Kingdom

Running title: Antifungal and modelling studies of azoles 


\section{Acknowledgments}

This study was funded by grants from The Scientific and Technological Research Council of Turkey (TÜBITAK) (113S060, 114S862) and Hacettepe University Scientific Research Projects Coordination Unit (014 D09 301 001-703, TPT-2015-6794, TDK-2017-14965). We would like to thank Prof. Erhan Palaska for providing the mass spectrum data and Prof. Serdar Durdağı for his contributions to the molecular modelling studies.

* Correspondence: Suat Sari, PhD

Hacettepe University Faculty of Pharmacy

Department of Pharmaceutical Chemistry

06100 Sihhiye Ankara/TURKEY

Tel.: + 903123051872

Fax: + 903123053272

e-mail: suat.sari@hacettepe.edu.tr

suat_sari@yahoo.com

suat1039@gmail.com

\section{Abstract}

Systemic Candida infections pose a serious public health problem with high morbidity and mortality. C. albicans is the major pathogen identified in candidiasis, however non-albicans Candida spp. with antifungal resistance are now more prevalent. Azoles are first-choice antifungal drugs for candidiasis, however they are ineffective for certain infections caused by the resistant strains. Azoles block ergosterol synthesis by inhibiting fungal CYP51, which leads to disruption of fungal membrane permeability. In this study, we screened for antifungal activity of an in-house azole library of 65 compounds to identify hit matter followed by a molecular modelling study for their CYP51 inhibition mechanism. Antifungal susceptibility tests against standard Candida spp. including C. albicans revealed derivatives 12 and 13 as highly active. Furthermore, they showed potent antibiofilm activity as well as neglectable cytotoxicity in a mouse fibroblast assay. According to molecular docking studies 12 and 13 have the necessary binding characteristics for effective inhibition of CYP51. 
Finally, molecular dynamics (MD) simulations of the C. albicans CYP51 (CACYP51) homology model's catalytic site complexed with $\mathbf{1 3}$ was stable demonstrating excellent binding.

1. Keywords: Biological Screening; Molecular Modeling; Structure-Based Drug Design

\section{Introduction}

Systemic fungal infections, which are mostly nosocomial due to immune-suppressing conditions, have attracted attention lately as a serious public health threat. Candida spp. is the major pathogenic genus of fungi found in humans and among the most prevalent in all types of systemic infections. C. albicans is the most common species identified in candidiasis, however the rising number intrinsically drug resistant non-Candida species is alarming (Wong, Samaranayake, \& Seneviratne, 2014).

Among the main antifungal classes (polyenes, azoles, echinocandins, pyrimidines) azoles are the first-line antifungals due to their wide spectrum of efficacy and systemic availability. However, being widely used has led to increased azole resistance of fungal strains (Graybill, 1992). Biofilms, a form of pathogen colonies found on biotic and nonbiotic surfaces featuring structural matrices and extracellular polymers, are known to contribute to virulent pathogenic fungi. Most antifungal compounds were reported to be effective against biofilms only at much higher doses compared to their planktonic forms (Silva, Rodrigues, Araujo, Rodrigues, \& Henriques, 2017). Therefore, new and improved azole derivatives are needed for invasive and systemic mycoses.

Azoles exert their antifungal effects by inhibiting fungal lanosterol $14 \alpha$-demethylase (CYP51), which in turn inhibits biosynthesis of the crucial ergosterol found in fungal cell membranes. Lack of ergosterol and excess lanosterol finally leads to disruption of cell membrane and loss of vital cytoplasmic components (Madhosingh \& Southwick, 2012).

Recent studies have taken advantage of property-based, ligand based, and structurebased methods, or their combinations, to identify and optimize fungal CYP51 azole inhibitors (Dogan et al., 2017; Sun, Huang, \& Liu, 2017; Sun, Zhang, Liu, Hou, \& Liu, 2018; 
Thamban Chandrika et al., 2018; Wu et al., 2018; Yates, Garvey, Shaver, Schotzinger, \& Hoekstra, 2017). In these studies not only several antifungal hits were identified but some key residues for the enzyme inhibition were also determined in reference to biological studies.

In this study, we screened antifungal properties of an in-house azole library (Table 1), tested for cytotoxic effects of the hit matter found against healthy cells, and evaluated their possible mechanism of action in silico. The $60+$ azole derivatives that make up the library fall into four structural classes: 1-(4-Chlorophenyl)-2-(1H-imidazol-1-yl)ethanone oxime esters (5-21), 1-(4-chlorophenyl)-2-(1H-1,2,4-triazol-1-yl)ethanone oxime esters (22-37), 2-(1H-imidazol-1-yl)-1-phenylethanol esters (38-51), 1-(4-Chlorophenyl)-2-(1Himidazol-1-yl)ethanol esters (52-65). The library also includes four synthons of these esters: 1-(4-Chlorophenyl)-2-(1H-imidazol-1-yl)ethanone (1), 1-(4-chlorophenyl)-2-(1Himidazol-1-yl)ethanone oxime (2), 1-(4-chlorophenyl)-2-(1H-1,2,4-triazol-1-yl)ethanone (3), 1-(4-chlorophenyl)-2-(1H-1,2,4-triazol-1-yl)ethanone oxime (4). Of the library compounds, 62 are previously reported as anticonvulsants (Doğan, 2012; Doğan et al., 2018; Porretta et al., 1993; S. Sari et al., 2017; Suat Sari, Kaynak, \& Dalkara, 2018) albeit three $(\mathbf{1 7}, \mathbf{1 8}$, and $\mathbf{3 7})$ are new structures. Antifungal activity of 1-4 were previously reported by Porretta et al. (1993). These results suggested that our azole collection was potentially an excellent source of antifungal compounds. Thus a screening study was initiated for antifungal activity using a number of standard susceptible fungal strains as well as testing against a resistant isolate, biofilms, cytotoxicity and finally a molecular modelling to shed light on the molecular mechanism of these active compounds.

\section{Materials and methods}

\subsection{Chemistry}

All the chemical reagents were obtained from commercial suppliers. Merck Kieselgel 60 F254 aluminium plates were used for thin layer chromatography to monitor the reactions and the spots were determined under $254 \mathrm{~nm}$ UV light using chloroformmethanol (90:10) as mobile phase. Melting points $(\mathrm{mp})$ were recorded on a ThomasHoover capillary melting point apparatus (USA) and uncorrected. IR spectra were 
recorded as reciprocal centimetres $\left(\mathrm{cm}^{-1}\right)$ using PerkinElmer FT-IR System Spectrum BX (USA). ${ }^{1} \mathrm{H}-\mathrm{NMR}(400 \mathrm{MHz})$ and ${ }^{13} \mathrm{C}-\mathrm{NMR}(75 \mathrm{MHz})$ spectra were recorded with Varian Mercury 400 FT (USA) and Bruker Avonce 600 Ultrashield $^{\mathrm{TM}}$ (Germany) NMR spectrometers, respectively. LC-MS spectra were recorded with Micromass ZQ mass spectrometer (USA) connected with Waters Alliance HPLC (USA) with the electrospray ionization (ESI+) method and MassLynx 4.1 software. Elemental analyses were performed by LECO 932 CHNS elemental analysis apparatus (USA) and the results are reported as percentages (\%). Compounds were dissolved in dimethyl sulfoxide (DMSO$d_{6}$ ) for NMR spectroscopy and the chemical shifts are reported as $\delta(p p m)$ values using tetramethylsilane as internal reference. The splitting patterns were noted as s (singlet), $d$ (doublet), $t$ (triplet), q (quartet), m (multiplet), and dd (doublet of doublet).

\subsubsection{General synthetic procedures}

1-(4-Chlorophenyl)-2-(1H-imidazol-1-yl)ethanone-O-(4-chlorobenzoyl) oxime (17), 1-(4chlorophenyl)-2-(1H-imidazol-1-yl)ethanone-O-(2,4-dichlorobenzoyl) oxime (18), and 1(4-chlorophenyl)-2-(1H-1,2,4-triazol-1-yl)ethanone-O-(4-phenylbenzoyl) oxime (37) were prepared according to the Steglich esterification as outlined in Scheme 1 (Neises \& Steglich, 1978). A mixture of 4-dimethylaminopyridine (DMAP) $(0.27 \mathrm{mmol})$ and $N, N^{\prime}-$ dicyclohexylcarbodiimide (DCC) $(4 \mathrm{mmol})$ in dry dichloromethane (DCM) was added dropwise to a mixture of 1-(4-chlorophenyl)-2-(1H-imidazol-1-yl)ethanone oxime (2) (for 17 and 18) or 1-(4-chlorophenyl)-2-(1H-1,2,4-triazol-1-yl)ethanone oxime (4) (for 37) (4 mmol) and proper carboxylic acid (4 mmol) in dry DCM at $0-5{ }^{\circ} \mathrm{C}$. The mixture was allowed to stir for 0.5 hour at $0-5{ }^{\circ} \mathrm{C}$ then for an additional 3-6 hours at room temperature. The resulting precipitate was filtered off, the filtrate was dried by evaporation, converted to its hydrochloride $(\mathrm{HCl})$ salts using ethereal solution of gaseous $\mathrm{HCl}(\mathrm{gHCl})$, and, finally, crystallized from acetone. 
hydrochloride (17): The reaction of $4 \mathrm{mmol} 2$ and $4 \mathrm{mmol}$ 4-chlorobenzoic acid gave 17 as off-white powder (1.21 g, 73.5\%). Mp: $161-2{ }^{\circ} \mathrm{C} ;{ }^{1} \mathrm{H}$ NMR (400 MHz, DMSO-d 6 ): $\delta=6.04$ $\left(\mathrm{s}, 2 \mathrm{H}, \mathrm{CH}_{2}\right), 7.55-7.60\left(\mathrm{~m}, 3 \mathrm{H}, 4\right.$-chlorobenzene $\mathrm{H}^{3,5}$, imidazole $\left.\mathrm{H}^{4}\right), 7.69(\mathrm{~d}, \mathrm{~J}=8.4 \mathrm{~Hz}, 2 \mathrm{H}$, 4- chlorobenzene $\left.H^{3^{\prime}, 5^{\prime}}\right)$, 7.75-7.78 $\left(\mathrm{m}, 3 \mathrm{H}\right.$, 4-chlorobenzene $\mathrm{H}^{2,6}$, imidazole $\left.\mathrm{H}^{5}\right), 8.16(\mathrm{~d}$, $J=8.8 \mathrm{~Hz}, 2 \mathrm{H}$, 4-chlorobenzene $\left.\mathrm{H}^{2}, 6^{\prime}\right), 9.27 \mathrm{ppm}\left(\mathrm{s}, 1 \mathrm{H}\right.$, imidazole $\left.\mathrm{H}^{2}\right) ;{ }^{13} \mathrm{C}-\mathrm{NMR}(75 \mathrm{MHz}$, DMSO- $\mathrm{d}_{6}$ ): $\delta=44.50\left(\mathrm{CH}_{2}\right), 121.09$ (imidazole $\mathrm{C}^{5}$ ), 122.36 (imidazole $\mathrm{C}^{4}$ ), 126.53 (4chlorobenzene $C^{1^{\prime}}$ ), 128.93-131.35 (4-chlorobenzene $C^{1-3,5,6}, 4$-chlorobenzene $C^{2^{\prime}, 3^{\prime}, 5^{\prime}, 6^{\prime}}$ ), 136.07 (4-chlorobenzene $C^{4}$ ), 136.42 (imidazole $C^{2}$ ), 139.17 (4-chlorobenzene $C^{4}$ ), 160.43 (CNO), 161.60 ppm (CO); IR (ATR): 3086, 3009, 2965, 1743, $1177 \mathrm{~cm}^{-1}$; MS (ESI+) $\mathrm{m} / \mathrm{z}: 398[\mathrm{M}+2+\mathrm{Na}]^{+}, 396\left([\mathrm{M}+\mathrm{Na}]^{+}, 100 \%\right), 378\left([\mathrm{M}+4+\mathrm{H}]^{+}\right), 376\left([\mathrm{M}+2+\mathrm{H}]^{+}\right), 374$ $\left([\mathrm{M}+\mathrm{H}]^{+}\right)$; Anal. calcd. for $\mathrm{C}_{18} \mathrm{H}_{14} \mathrm{Cl}_{3} \mathrm{~N}_{3} \mathrm{O}_{2} .1 / 2 \mathrm{H}_{2} \mathrm{O}: \mathrm{C} 51.51, \mathrm{H} 3.60, \mathrm{~N} 10.01$, found: 51.83, H 3.40, N 10.16 .

\section{1-(2,4-Dichlorophenyl)-2-(1H-imidazol-1-yl)ethanone-O-(4-chlorobenzoyl)}

hydrochloride (18): The reaction of $4 \mathrm{mmol} 2$ and $4 \mathrm{mmol}$ 2,4-dichlorobenzoic acid gave 18 as off-white powder (0.82 g, 46\%). Mp: $156-9{ }^{\circ} \mathrm{C} ;{ }^{1} \mathrm{H}$ NMR (400 MHz, DMSO-d 6 ): $\delta=5.91\left(\mathrm{~s}, 2 \mathrm{H}, \mathrm{CH}_{2}\right), 7.53-7.56\left(\mathrm{~m}, 3 \mathrm{H}\right.$, 4-chlorobenzene $\mathrm{H}^{3,5}$, imidazole $\left.\mathrm{H}^{4}\right), 7.64$ (dd, $J_{1}=8.4 \mathrm{~Hz}, J_{2}=2.0 \mathrm{~Hz}, 1 \mathrm{H}, 2$,4-dichlorobenzene $\left.\mathrm{H}^{5}\right), 7.67\left(\mathrm{t}, J_{1}=1.6 \mathrm{~Hz}, J_{2}=1.6 \mathrm{~Hz}\right.$, imidazole $\left.H^{5}\right), 7.74\left(d, J=8.8 \mathrm{~Hz}\right.$, 4-chlorobenzene $\left.H^{2,6}\right), 7.88(d, J=2.0 \mathrm{~Hz}, 1 \mathrm{H}$, 2,4-dichlorobenzene $\left.\mathrm{H}^{3}\right), 8.04\left(\mathrm{~d}, J=7.1 \mathrm{~Hz}, 1 \mathrm{H}, 2\right.$,4-dichlorobenzene $\left.\mathrm{H}^{6}\right), 9.17\left(\mathrm{~s}, 1 \mathrm{H}\right.$, imidazole $\left.\mathrm{H}^{2}\right) ;{ }^{13} \mathrm{C}$-NMR $\left(75 \mathrm{MHz}, \mathrm{DMSO}-\mathrm{d}_{6}\right): \delta=44.67\left(\mathrm{CH}_{2}\right), 121.23$ (imidazole $\mathrm{C}^{5}$ ), 122.25 (imidazole $\mathrm{C}^{4}$ ), 126.64 (2,4-dichlorobenzene $\left.\quad C^{1}\right), \quad 127.88 \quad$ (2,4-dichlorobenzene $\left.\quad C^{5}\right), \quad 128.95-129.66 \quad$ (4chlorobenzene $C^{2,3,5,6}$, 4-chlorobenzene $\left.C^{1}\right), 130.65$ (2,4-dichlorobenzene $C^{3}$ ), 133.10 (2,4-dichlorobenzene $\left.C^{6}\right), 133.70$ (2,4-dichlorobenzene $C^{2}$ ), 136.17 (4-chlorobenzene $C^{4}$ ), 136.49 (imidazole $C^{2}$ ), 138.14 (2,4-dichlorobenzene $C^{4}$ ), 160.74 (CNO), 160.80 ppm (CO); IR (ATR): 3055, 2940, 1754, $1141 \mathrm{~cm}^{-1} ; \mathrm{MS}(\mathrm{ESI}+) \mathrm{m} / \mathrm{z}: 436\left([\mathrm{M}+6+\mathrm{Na}]^{+}\right), 434$ $\left([\mathrm{M}+4+\mathrm{Na}]^{+}\right), 432\left([\mathrm{M}+2+\mathrm{Na}]^{+}\right), 430\left([\mathrm{M}+\mathrm{Na}]^{+}, 100 \%\right), 410\left([\mathrm{M}+2+\mathrm{H}]^{+}\right), 408\left([\mathrm{M}+\mathrm{H}]^{+}\right)$; Anal. calcd. for $\mathrm{C}_{18} \mathrm{H}_{13} \mathrm{Cl}_{4} \mathrm{~N}_{3} \mathrm{O}_{2}$ : C 48.57, $\mathrm{H}$ 2.95, N 9.44, found: 48.89, H 3.29, N 9.80. 
1-(2,4-Dichlorophenyl)-2-(1H-1,2,4-triazol-1-yl)ethanone-O-(4-phenylbenzoyl) oxime hydrochloride (37): The reaction of $4 \mathrm{mmol} 4$ and $4 \mathrm{mmol} 4$-phenylbenzoic acid gave 37 as off-white powder (0.71 g, 39\%). Mp: $155-7{ }^{\circ} \mathrm{C} ;{ }^{1} \mathrm{H}$ NMR (400 MHz, DMSO-d 6 ): $\delta=5.96$ $\left(\mathrm{s}, 2 \mathrm{H}, \mathrm{CH}_{2}\right), 7.44-7.48\left(\mathrm{~m}, 2 \mathrm{H}\right.$, benzene $\left.\mathrm{H}^{4}\right)$, 7.52-7.57 (m, $4 \mathrm{H}$, 4-chlorobenzene $\mathrm{H}^{3,5}$, benzene $\left.H^{3,5}\right), 7.79\left(d, J=7.6 \mathrm{~Hz}, 2 \mathrm{H}\right.$, benzene $\left.H^{2,6}\right), 7.83(d, J=8.8 \mathrm{~Hz}, 2 \mathrm{H}, 4-$ phenylbenzene $\left.H^{2,6}\right), 7.90\left(d, J=8.0 \mathrm{~Hz}, 2 \mathrm{H}\right.$, 4-chlorobenzene $\left.H^{2,6}\right), 7.96(s, 1 \mathrm{H}$, triazole $\left.\mathrm{H}^{3}\right), 8.21\left(\mathrm{~d}, \mathrm{~J}=8.8 \mathrm{~Hz}, 2 \mathrm{H}, 4\right.$-phenylbenzene $\left.\mathrm{H}^{2,6}\right), 8.77 \mathrm{ppm}\left(\mathrm{s}, 1 \mathrm{H}\right.$, triazole $\left.\mathrm{H}^{5}\right) ;{ }^{13} \mathrm{C}$-NMR (75 MHz, DMSO- $\mathrm{d}_{6}$ ): $\delta=44.78\left(\mathrm{CH}_{2}\right), 126,49$ (benzene $\mathrm{C}^{4}$ ), 127.08 (4-phenylbenzene $\mathrm{C}^{3,5}$ ), 127.22 (benzene $C^{2,6}$ ), 128.61 (4-phenylbenzene $C^{1}$ ), 128.84 (4-chlorobenzene $C^{3,5}$ ), 129.16 (4-chlorobenzene $C^{2,6}$ ), 129.50 (benzene $C^{3,5}$ ), 130.33 (4-phenylbenzene $C^{2,6}$ ), 130.78 (4-chlorobenzene $C^{1}$ ), 135.90 (4-chlorobenzene $C^{4}$ ), 138.68 (benzene $C^{1}$ ), 145.04 (triazole $C^{5}$ ), 145.49 (4-phenylbenzene $C^{4}$ ), 151.33 (triazole $C^{3}$ ), 160.26 (CNO), 162.34 ppm (CO); IR (ATR): 3059, 2984, 1746, $1184 \mathrm{~cm}^{-1} ; \mathrm{MS}(\mathrm{ESI}+) \mathrm{m} / \mathrm{z}: 441\left([\mathrm{M}+2+\mathrm{Na}]^{+}\right), 439$ $\left([\mathrm{M}+\mathrm{Na}]^{+}, \% 100\right), 419\left([\mathrm{M}+2+\mathrm{H}]^{+}\right), 417\left([\mathrm{M}+\mathrm{H}]^{+}\right)$; Anal. calcd. for $\mathrm{C}_{23} \mathrm{H}_{18} \mathrm{Cl}_{2} \mathrm{~N}_{4} \mathrm{O}_{2}: \mathrm{C}$ 60.94, H 4.00, N 12.36, found: 61.34, H 3.70, N 12.44 .

\subsection{Biological assays}

\subsubsection{Microdilution method for antifungal susceptibility tests}

Antifungal activities of the compounds were tested against Candida spp. (C. albicans ATCC 90028, C. krusei ATCC 6258, and C. parapsilosis ATCC 90018) by the broth microdilution method. The minimum inhibitor concentration (MIC) values were determined according to the Clinical and Laboratory Standards Institute (CLSI) reference documents using fluconazole as reference compound. Isolates stored at $-80{ }^{\circ} \mathrm{C}$ in glycerol were thawed and subcultured twice onto Sabouraud dextrose agar prior to testing. Broth microdilution was performed using RPMI 1640 broth (ICN-Flow, Aurora, $\mathrm{OH}$, USA, with glutamine, without bicarbonate and with $\mathrm{pH}$ indicator) buffered to $\mathrm{pH} 7.0$ with 3- $N$-morpholinopropanesulfonic acid (MOPS; Sigma, USA). The inoculum densities were prepared from 24-hour subcultures. The final test concentration of fungi was 0.5 to $2.5 \times 10^{3} \mathrm{cfu} / \mathrm{ml}$. Fluconazole was dissolved in sterile deionized distilled water (64$0.0625 \mu \mathrm{g} / \mathrm{ml}$ ) and the compounds were solvated in DMSO (Sigma, USA). Final twofold concentrations of the compounds were prepared in the wells of the microtiter plates, 
between 1024 and $0.25 \mu \mathrm{g} / \mathrm{ml}$. The plates were incubated at $35{ }^{\circ} \mathrm{C}$ for 48 hours. MIC values were read as the lowest concentration of test compound that completely inhibited visual growth.

\subsubsection{Biofilm susceptibility assay/antibiofilm activity}

C. albicans SC5314 biofilms were grown in the Calgary Biofilm Device (commercially available as the MBEC Assay ${ }^{\mathrm{TM}}$ for Physiology \& Genetics, P \& G, Innovotech Inc., Edmonton, Alberta, Canada) according to the MBEC ${ }^{\mathrm{TM}}$ assay protocol, a standard ASTM method, as supplied by the manufacturer. Aliquots of $150 \mu \mathrm{l}$ final inoculum suspension (106 cfu/ml) were transferred to each of the test wells and the MBEC assay plate lids with 96 pegs were placed into the microtiter plates. The plates were incubated for 24 hours at $37{ }^{\circ} \mathrm{C}$ to form mature biofilm. After 24 hours, the peg lids of the MBEC assay plates were rinsed three times with $100 \mu \mathrm{l}$ 0.9\% physiological saline (PS), then transferred to a 'challenge' plate. Finally, $200 \mu \mathrm{l}$ serial twofold dilutions of each compound were subsequently added to each well and they were incubated for 24 hours at $35{ }^{\circ} \mathrm{C}$. The concentration range of the compounds was arranged as $512-0.5 \mu \mathrm{g} / \mathrm{ml}$ in columns 1-11, respectively. Positive growth control and sterility control were included in each assay plate. After treatment of the biofilm for 24 hours, the peg lids were rinsed three times in $0.9 \%$ PS and transferred to a 'recovery' plate, each well contained RPMI 1640 supplemented with $2 \%$ glucose. The plates were sonicated for five minutes to remove the biofilms into recovery media and the peg lids were discarded. The recovery plates were incubated overnight and optical densities of the wells were measured at 550 $\mathrm{nm}$ by spectrophotometer. The plates were also visually checked after 24 hours for turbidity, clear wells were taken as evidence of biofilm eradication. The minimum biofilm eradicator concentration (MBEC) values were determined by identifying the lowest antibiotic concentration that prevents regrowth of $C$. albicans from the treated biofilm. The minimum biofilm inhibitor concentration (MBIC) values were also determined by identifying the minimum concentration that prevents the initial formation of biofilm checking turbidity visually in the wells. 


\subsubsection{Cytotoxicity assay}

The effects of 12 and 13 on cell viability were evaluated according to 3-(4,5dimethylthiazol-2-yl)-2,5-diphenyltetrazolium bromide (MTT) assay with slight changes (Ohguro, Fukuda, Sasabe, \& Tano, 1999) based on colorimetric measuring the absorbance of formazan crystals formed from tetrazolium by mitochondrial reductase due to increased dehydrogenase activity of proliferating cells. 12 and 13 were applied to mouse fibroblast cell line (L929) at eight different concentrations from 0.025 to 5 and 0.1 to $20 \mu \mathrm{g} / \mathrm{ml}$, respectively, which include their MIC values, and the cell line was exposed to the compounds for 48 hours. The cells without compound exposure were used as negative control and those treated with $10 \%$ DMSO as positive control. At the end of each exposure period $1 \mathrm{mg} / \mathrm{ml}$ MTT solution in $100 \mu \mathrm{LBPS}$ was added to each well following removal of compound solution and incubated for 3 hours. Formazan crystals which formed during this process were dissolved by addition of $90 \mu \mathrm{DMSO}$, the plates were stirred on a horizontal shaker for 15 minutes and the absorbance values were determined at $570 \mathrm{~nm}$. Cell viability values were determined as percentages (\%) according to the absorbance values of the cells treated with compounds considering those of the negative control cells as $100 \%$. Each experiment was performed in triplicate.

\subsection{Molecular modelling}

The ligands to be used in molecular modelling studies were generated using MacroModel (2018-1: Schrödinger, LLC, NY, 2018) and optimized using OPLS_2005 force field parameters and conjugate gradient method (Banks et al., 2005; Polak \& Ribiere, 1969). 


\subsubsection{Calculation of the molecular descriptors}

The molecular descriptors used for evaluating the chemical space were calculated using QikProp (2018-1: Schrödinger, LLC, NY, 2018). The reliability of QikProp is established for the calculated descriptors (loakimidis, Thoukydidis, Mirza, Naeem, \& Reynisson, 2008).

\subsubsection{Molecular docking}

Molecular docking studies were performed using GOLD (v5.2.2, CCDC Software Ltd., Cambridge, UK, 2013), AutoDock (v4.2.6), AutoDock Vina (v1.1.2), and Glide (2018-1: Schrödinger, LLC, NY, 2018) (Friesner et al., 2004; Friesner et al., 2006; Halgren et al., 2004; Jones, Willett, Glen, Leach, \& Taylor, 1997; Morris et al., 2009; Trott \& Olson, 2010). We used a homology model of CAYP51 as receptor and defined the modelling, optimization, validation of this model and its preparation for molecular docking in detail in our previous study (Dogan et al., 2017). The centroid of itraconazole (ITR) in the binding site of CACYP51 (19.42 10.25 17.44) was taken as the centre of search space and grid maps were prepared for AutoDock using AutoGrid. For docking simulations on GOLD GoldScore (GS) (Jones et al., 1997), ChemScore (CS) (Eldridge, Murray, Auton, Paolini, \& Mee, 1997; Verdonk, Cole, Hartshorn, Murray, \& Taylor, 2003), Astex Statistical Potential (ASP) (Korb, Stutzle, \& Exner, 2009), and Piecewise Linear Potential (CHEMPLP or PLP) (Mooij \& Verdonk, 2005) fitness functions were used at 100\% efficiency and 50 runs for each ligand and each scoring function with early termination enabled. For AutoDock each ligand was docked 50 times to the receptor using Lamarckian genetic algorithm on at medium exhaustiveness. On AutoDock Vina, where docking operations are fully automated, the default settings were used. AutoDockTools was used for docking operation on AutoDock and AutoDock Vina. On Glide induced fit docking protocol was applied. In this method, receptor grid is automatically created using the same centroid coordinates above and an initial docking with lowered receptor and ligand van der Waals scales was performed with Glide generating up to 20 poses per ligand. The protocol then used Prime (2018-1: Schrödinger, LLC, NY, 2018) to refine the residues within $5 \AA$ of docked ligands except heme. Trimming of residue side chains was not allowed and the top 20 scoring structures were redocked to the refined binding site 
using Glide at standard precision. On AutoDock, AutoDock Vina, and GOLD the receptor was kept rigid. Top-scoring pose clusters for each ligand on each software were identified and the best poses were determined upon visual evaluation.

\subsubsection{Simulations}

We used NAMD (v2.10) and VMD (v1.9.2) for system preparation, MD simulation and analysis of the results (Humphrey, Dalke, \& Schulten, 1996; Phillips et al., 2005). On VMD we created the systems of ligand-bound CACYP51 and solvated it in a water box with a $5-\AA ̊$ layer of water on each face. The total number of atoms for each system was about 60000. CHARMM36 force-field with CMAP corrections was used for the protein and solvent, CHARMM General Force-Field (v3.1) via cgenff.paramchem.org server (v1.0) was used for the ligands, and water molecules were modelled using TIP3P water model (Best et al., 2012; Jorgensen, Chandrasekhar, Madura, Impey, \& Klein, 1983; A. D. MacKerell et al., 1998; A. D. MacKerell, Jr., Feig, \& Brooks, 2004; Vanommeslaeghe et al., 2010; Yu, He, Vanommeslaeghe, \& MacKerell, 2012). We used particle mesh Ewald (PME) method with grid sizes 114, 103, and 84 (Darden, York, \& Pedersen, 1993) and full updates at every $2 \mathrm{fs}$. Harmonic potential constraints $\left(5 \mathrm{kcal} / \mathrm{mol}^{*} \AA^{2}\right)$ were applied on the backbone atoms of the membrane-embedded residues, $\mathrm{Fe}^{2+}$ of heme, and $\mathrm{S}^{-}$of heme-coordinating cysteine. Heme was patched to keep planar. Systems with 13 bound to the active site and without any ligand (apo) were first minimized at 100 steps then run for $20 \mathrm{~ns}$ at constant temperature $(310 \mathrm{~K})$ and pressure ( $1 \mathrm{~atm})$ (NPT ensemble) with integration time step 2 fs, non-bonded cut-off starting at $10 \AA$, pair list set to $14 \AA$ and updated every 10 cycles using CUDA GPU acceleration on NAMD. SHAKE algorithm was used for hydrogens, and the coordinates were saved every 500 steps. Trajectory analyses were performed using VMD. 


\section{Results and discussion}

\subsection{Chemistry}

Compounds 17, 18, and $\mathbf{3 7}$ were synthesized through esterification of proper carboxylic acids with $\mathbf{2}$ for $\mathbf{1 7}$ and $\mathbf{1 8}$ and $\mathbf{4}$ for $\mathbf{3 7}$ in moderate to high yields. The spectral and elemental analysis data proved their structures and purity. The ${ }^{1} \mathrm{H}$-NMR spectra of the compounds indicated that they were obtained as single geometric isomers, but it was not possible to determine whether they are $E$ or $Z$.

\subsection{Antifungal activity}

The MIC values of 1-65 were determined against standard ATCC type cultures of $C$. albicans and two non-albicans Candida spp. (C. krusei and C. parapsilosis) (Table 2). In general, the compounds were more potent against $C$. parapsilosis than $C$ albicans. High MIC values were determined against C. krusei, which is intrinsically azole-resistant (Whaley et al., 2016). In general, compounds with imidazole were more active than those with 1,2,4-triazole. 12 and 13 stood out as the most active compounds in the series with lower MIC values than those of fluconazole against all the three standard Candida spp. Especially, 13 was highly potent with less than $1 \mu \mathrm{g} / \mathrm{ml} \mathrm{MIC}$ value against $C$. albicans and C. parapsilosis, however for C. krusei, again higher concentrations were needed. Unfortunately, against the azole-resistant clinical isolate of $C$. tropicalis, no significant activity was observed for the tested compounds.

Derivatives 12 and 13 were further tested for their antibiofilm activity. Their MBIC and MBEC values against biofilm were determined and compared with those of amphotericin $B$, an antifungal drug effective against clinical biofilms (Zarei Mahmoudabadi, Zarrin, \& Kiasat, 2014). Both compounds were potent in blocking biofilm growth as shown in Table 3. Derivative 13, again, was highly potent, with a dose lower than $1 \mu \mathrm{g} / \mathrm{ml}$. None of the compounds, however, showed significant biofilm eradicator effect. 


\subsection{Cytotoxicity}

The effects of $\mathbf{1 2}$ and $\mathbf{1 3}$ on cell viability of the mouse fibroblast cell line was tested to evaluate their toxicity on healthy cells and gauge their selectivity to pathogens over host cells. In the case of 12 , the viability percentage was in excess of $100 \%$ when its concentration increased from 0.025 to $5 \mu \mathrm{g} / \mathrm{ml}$ (Figure 1). 13 was tested at up to 20 $\mu \mathrm{g} / \mathrm{ml}$ since its MIC value was much higher than 12 for $C$. albicans. Nevertheless, the viability percentage was not less than $75 \%$ at this concentration. These results clearly show that $\mathbf{1 2}$ and $\mathbf{1 3}$ are not cytotoxic for host cells at their active doses.

\subsection{Molecular modelling}

\subsubsection{Evaluation of the chemical space}

About $40 \%$ of drug candidates fail in clinical trials due to poor pharmacokinetic properties, which cause increasing cost of new drug development. Addressing pharmacokinetics in early stage drug discovery is important to save cost and time. We provided the calculated values a number of pharmaceutically relevant molecular descriptors ( $\mathrm{MW}$ - molecular weight, log $\mathrm{P}$ - octanol water partition, HD - hydrogen bond donors, HA - hydrogen bond acceptors, PSA - polar surface area and RB rotatable bonds) for 12 and $\mathbf{1 3}$ in Table 4 (The calculated values for the rest of the compounds are given in Table S1 of Supporting Information). For definitions of lead-like, drug-like and Known Drug Space (KDS) regions see Table S2 of Supporting Information and references therein (Zhu, Logan, \& Reynisson, 2012).

In general, the in-house azole collection adheres to the lead- and drug-like definitions making the excellent candidates for further development. MW lies in the region of 220$417 \mathrm{~g} / \mathrm{mol}$ putting squarely in the lead/drug-like chemical space. The log P values range from 1.3 to 5.4 with three derivatives $(\mathbf{1 4}, \mathbf{2 1}$ and $\mathbf{6 5})$ reaching into KDS. Only two azoles have HD putting this descriptor in lead-like space whereas HA fits into drug-like space as well as RB. Finally, PSA straddles the lead/drug-like chemical space. 
For further analysis the Know Drug Indexes $2 \mathrm{a}$ and $2 \mathrm{~b}\left(\mathrm{KDI}_{2 \mathrm{a} / 2 \mathrm{~b}}\right)$ were also derived (Eurtivong \& Reynisson, 2018). The KDI reflect the overall balance of the six molecular properties calculated based on the statistical distribution of KDS and derivation of an index for each descriptor. $\mathrm{KDI}_{2 \mathrm{a}}$ is an additive value with a maximum of 6.0 and $\mathrm{KDI}_{2 \mathrm{~b}}$ the indexes are then multiplied giving 1.0 as its maximum. The average for $\mathrm{KDI}_{2 \mathrm{a}}$ for known drugs is $4.08( \pm 1.27)$ and the azoles lie in the range of 5.07 to 5.65 , the $\mathrm{KDI}_{2 \mathrm{~b}}$ gives a range of 0.32 to 0.68 for the azoles with the average of know drugs being $0.18( \pm 0.20)$ (Table S1). Thus, it is clear that the azole collection is excellent in terms of balanced physicochemical properties as compared to known drugs. The active compounds; $\mathbf{1 2}$ has $K D I$ values of $5.41(2 A)$ and $0.51(2 B)$ with 13 having even better results with $5.61(2 A)$ and $0.64(2 B)$. Better, KDI number reflect enhanced bioavailability and the higher values of 13 as compared to $\mathbf{1 2}$ can, partially explain the superior efficacy of the former.

\subsubsection{Molecular docking studies}

The heme cofactor found in cytochrome $\mathrm{P} 450$ enzymes plays a key role in their catalytic processes of the enzymes. CYP51 inhibitors displace $\mathrm{O}_{2}$ and form the $6^{\text {th }}$ axial coordination with the $\mathrm{Fe}^{2+}$ placed at the centre of heme molecules. This $\mathrm{Fe}^{2+}$ makes four horizontal coordination with the $\mathrm{N}$ of each pyrrole and one coordination with $\mathrm{S}^{-}$of a cysteine sidechain of the protein. Azole antifungals share a common scaffold which consists of an azole ring that interacts with heme, an aryl group connected to the azole ring through an alkylene linker, and a tail group that fills the channel which tunnels between the entry of the catalytic site and the cavity where heme is present (De Vita et al., 2012).

The CACYP51 homology model used in this study features the full protein including the anchor region not available in current CACYP51 crystal structures. This region is attached to the endoplasmic reticulum bilayer membrane in mammals as eukaryotic CYP51s are bitopic membrane proteins (Monk et al., 2014). The model also includes ITR, a tight binder of CYP51 and an azole antifungal drug, in the catalytic site. 
There are many docking software available, free and commercial, with diverse algorithms and scoring functions. These algorithms may yield different results or consensus may be reached for certain cases, the latter being desirable for the sake of reliability. We performed a redocking study to evaluate how close the software/algorithms used in this study predict the binding mode of ITR regarding its original conformation in CACYP51 catalytic site. The results confirmed that the methods worked well (Table 5) as reflected in relatively low RMSD values and high affinity predictions by the scoring functions used.

Docking studies showed that 12 and 13 bound to the catalytic site of CACYP51 with high affinity evident in high positive values for GOLD fitness scores and low negative values for AutoDock, AutoDock Vina, and Glide scores (Table 6) (For the docking scores of the complete library from AutoDock and AutoDock Vina see Table S3 of the Supporting Information). Their binding modes were similar to those determined for azole antifungals in crystallography studies (Figure 2). According to the binding modes obtained from several software and algorithms the azole ring placed close to the heme and $\mathrm{Fe}^{2+}$, the 4-chlorobenzen fit in the cleft surrounded by Gly303, Ile304, and Met306 making hydrophobic contacts and the tail groups interacted with residues that form the active site gorge, e.g. Tyr118, Leu376, His377, Ser378, Phe380, Met508, Val509 (Figure 3). Most of these residues were found to be important for CACYP51 inhibition according to the in vitro mutagenesis studies (Morio, Loge, Besse, Hennequin, \& Le Pape, 2010) as well as molecular modelling studies with previously reported CACYP51 homology models (Dogan et al., 2017; Flowers, Colon, Whaley, Schuler, \& Rogers, 2015; Hoekstra et al., 2014; Iman \& Davood, 2014; Sheng et al., 2004).

For 12 and 13, the best binding mode was obtained from GS of GOLD and AutoDock (Figure 2), especially in terms of $\mathrm{Fe}^{2+}$ coordination and azole-heme $\pi-\pi$ interaction, which is governed by the distance between the azole $\mathrm{N}$ at the third position and $\mathrm{Fe}^{2+}$ (Table 7) and vertical orientation of azole and heme planes (Rupp, Raub, Marian, \& Holtje, 2005). Binding modes of 12 and $\mathbf{1 3}$ were very similar and perfectly aligned (Figure 3). 


\subsubsection{MD simulations}

The 13-CACYP51 complex obtained with GS of GOLD was solvated in water and MD simulations of the resulting system were run for $20 \mathrm{~ns}$, along with the inhibitor-free (apo) system. The RMSD values of the protein in the 13-bound CACYP51 simulation plateaued beneath $2 \AA$ (Figure 4A), while in the apo simulation protein displayed larger fluctuations especially between 2-8 ns and 15-20 ns (Figure 4B). The average RMS fluctuation (RMSF) of each residue of CACYP51 was analysed (Figure 4B) and some regions were observed to fluctuate more in the apo structure than in the 13-bound structure. Higher RMSF indicates higher flexibility during the MD simulation. Most of the residues which interacted with $\mathbf{1 3}$ (Figure $3 \mathrm{~B}$ ) coincides with the regions of greater fluctuations in the trajectory of the apo simulation (Table 8). This shows that the 13CACYP51 complex and the ligand-enzyme interactions of this complex identified in docking analyses are stabilizing the binding site of the protein.

Some of the residues with the highest RMSF gap were reported in mutagenesis studies. For instance Y121F was reported as an increasing mutation due to agricultural use of triazole antifungals (Parker et al., 2014), I304N, 1304T, and L376V were reported in the literature (Morio et al., 2010), and G307S was reported to be involved in azole resistance in combination with other mutations (Chau, Mendrick, Sabatelli, Loebenberg, \& McNicholas, 2004; Flowers et al., 2015).

\section{Conclusion}

In this study we report on the antifungal activity of 65 azole derivatives, three of which are novel. Two hit molecules were identified, namely 12 and 13, the latter of which showed excellent activity against standard C. albicans and C. parapsilosis. These compounds also displayed potent inhibitor effect against $C$. albicans biofilms and proved non-toxic to mouse fibroblast cells, however, lacked potency against a clinical azoleresistant $C$. tropicalis isolate and eradicator effect against the biofilms.

Derivatives 12 and 13 were predicted to be lead-like, drug-like, and excellent in terms of balanced physicochemical properties compared to known drugs as their KDI reflect. Considering the fact that azole antifungals act by inhibiting fungal CYP51, we docked $\mathbf{1 2}$ 
and 13 to the catalytic site of the CACYP51 homology model featuring full membrane spanning anchor domain, which we previously reported, using five different software/algorithms. The compounds satisfied the molecular determinants of CYP51 inhibition, GS of GOLD and AutoDock yielded best poses regarding imidazole N-heme $\mathrm{Fe}^{2+}$ distance and imidazole-heme plane orientation. Their docking scores were also good indicating high affinity to the enzyme catalytic site. MD simulations of apo, ITRbound, and 13-bound CACYP51 systems were run. 13-bound CACYP51 was stable and the binding interactions of this complex predicted by molecular docking were maintained according to the trajectories obtained from the MD simulations. Most residues involved in these interactions were biologically relevant and in accordance with previously reported in silico studies. The molecular modelling studies strongly indicates that fungal CYP51 inhibition is the mechanism for the antifungal efficacy of the active compounds of this series.

\section{Disclosure statement}

The authors declare no conflict of interest. 


\section{References}

Banks, J. L., Beard, H. S., Cao, Y., Cho, A. E., Damm, W., Farid, R., . . Levy, R. M. (2005). Integrated Modeling Program, Applied Chemical Theory (IMPACT). Journal of Computational Chemistry, 26(16), 1752-1780. doi:10.1002/jcc.20292

Best, R. B., Zhu, X., Shim, J., Lopes, P. E., Mittal, J., Feig, M., \& Mackerell, A. D., Jr. (2012). Optimization of the additive CHARMM all-atom protein force field targeting improved sampling of the backbone phi, psi and side-chain chi(1) and chi(2) dihedral angles. Journal of Chemical Theory and Computation, 8(9), 3257-3273. doi:10.1021/ct300400x

Chau, A. S., Mendrick, C. A., Sabatelli, F. J., Loebenberg, D., \& McNicholas, P. M. (2004). Application of real-time quantitative PCR to molecular analysis of Candida albicans strains exhibiting reduced susceptibility to azoles. Antimicrobial Agents and Chemotherapy, 48(6), 2124-2131. doi:10.1128/AAC.48.6.2124-2131.2004

CLSI (2008). Refence Method for Broth Dilution Antifungal Susceptibility Testing of Yeasts. $3^{\text {rd }}$ Ed. (M27-A3) Wayne: PA, USA.

Darden, T., York, D., \& Pedersen, L. (1993). Particle mesh Ewald: An N·log(N) method for Ewald sums in large systems. The Journal of Chemical Physics, 98(12), 10089-10092. doi:10.1063/1.464397

De Vita, D., Scipione, L., Tortorella, S., Mellini, P., Di Rienzo, B., Simonetti, G., . . . Palamara, A. T. (2012). Synthesis and antifungal activity of a new series of $2-(1 \mathrm{H}-$ imidazol-1-yl)-1-phenylethanol derivatives. European Journal of Medicinal Chemistry, 49, 334-342. doi:10.1016/j.ejmech.2012.01.034

Dogan, I. S., Sarac, S., Sari, S., Kart, D., Gokhan, S. E., Vural, I., \& Dalkara, S. (2017). New azole derivatives showing antimicrobial effects and their mechanism of antifungal activity by molecular modeling studies. European Journal of Medicinal Chemistry, 130, 124-138. doi:10.1016/j.ejmech.2017.02.035

Doğan, i. S. (2012). Studies on synthesis and biological activities of 1-phenyl/1-(4chlorophenyl)-2-(1H-imidazol-1-yl)ethanol esters. (PhD), Hacettepe University, Ankara.

Doğan, İ. S., Özdemir, Z., Sari, S., Bozbey, İ., Karakurt, A., \& Saraç, S. (2018). Synthesis, anticonvulsant activity, and molecular modeling studies of novel 1-phenyl/1-(4chlorophenyl)-2-(1H-triazol-1-yl)ethanol ester derivatives. Medicinal Chemistry Research, 27(9), 2171-2186. doi:10.1007/s00044-018-2225-6

Eldridge, M. D., Murray, C. W., Auton, T. R., Paolini, G. V., \& Mee, R. P. (1997). Empirical scoring functions: I. The development of a fast empirical scoring function to estimate the binding affinity of ligands in receptor complexes. Journal of Computer-Aided Molecular Design, 11(5), 425-445.

Eurtivong, C., \& Reynisson, J. (2018). The Development of a Weighted Index to Optimise Compound Libraries for High Throughput Screening. Molecular Informatics. doi:10.1002/minf.201800068

Flowers, S. A., Colon, B., Whaley, S. G., Schuler, M. A., \& Rogers, P. D. (2015). Contribution of clinically derived mutations in ERG11 to azole resistance in Candida 
albicans. Antimicrobial Agents and Chemotherapy, 59(1), 450-460. doi:10.1128/AAC.03470-14

Friesner, R. A., Banks, J. L., Murphy, R. B., Halgren, T. A., Klicic, J. J., Mainz, D. T., . . . Shenkin, P. S. (2004). Glide: a new approach for rapid, accurate docking and scoring. 1. Method and assessment of docking accuracy. Journal of Medicinal Chemistry, 47(7), 1739-1749. doi:10.1021/jm0306430

Friesner, R. A., Murphy, R. B., Repasky, M. P., Frye, L. L., Greenwood, J. R., Halgren, T. A., ... Mainz, D. T. (2006). Extra precision glide: docking and scoring incorporating a model of hydrophobic enclosure for protein-ligand complexes. Journal of Medicinal Chemistry, 49(21), 6177-6196. doi:10.1021/jm051256o

Graybill, J. R. (1992). Future directions of antifungal chemotherapy. Clinical Infectious Diseases, 14 Suppl 1, S170-181.

Halgren, T. A., Murphy, R. B., Friesner, R. A., Beard, H. S., Frye, L. L., Pollard, W. T., \& Banks, J. L. (2004). Glide: a new approach for rapid, accurate docking and scoring. 2. Enrichment factors in database screening. Journal of Medicinal Chemistry, 47(7), 17501759. doi:10.1021/jm030644s

Hoekstra, W. J., Garvey, E. P., Moore, W. R., Rafferty, S. W., Yates, C. M., \& Schotzinger, R. J. (2014). Design and optimization of highly-selective fungal CYP51 inhibitors. Bioorganic \& Medicinal Chemistry Letters, 24(15), 3455-3458. doi:10.1016/j.bmcl.2014.05.068

Humphrey, W., Dalke, A., \& Schulten, K. (1996). VMD: visual molecular dynamics. Journal of Molecular Graphics, 14(1), 33-38, 27-38.

Iman, M., \& Davood, A. (2014). Homology modeling of lanosterol 14 alpha-demethylase of Candida albicans and insights into azole binding. Medicinal Chemistry Research, 23(6), 2890-2899. doi:10.1007/s00044-013-0769-z

Innovotech Incorporated Manufacturer's Instructions: the MBECTM Physiology\&Genetics (P\&G), Assay for High-throughput Antimicrobial Susceptibility Testing of Biofilms. Retrieved from http://www.innovotech.ca

loakimidis, L., Thoukydidis, L., Mirza, A., Naeem, S., \& Reynisson, J. (2008). Benchmarking the Reliability of QikProp. Correlation between Experimental and Predicted Values. QSAR \& Combinatorial Science, 27(4), 445-456. doi:10.1002/qsar.200730051

Jones, G., Willett, P., Glen, R. C., Leach, A. R., \& Taylor, R. (1997). Development and validation of a genetic algorithm for flexible docking. Journal of Molecular Biology, 267(3), 727-748. doi:10.1006/jmbi.1996.0897

Jorgensen, W. L., Chandrasekhar, J., Madura, J. D., Impey, R. W., \& Klein, M. L. (1983). Comparison of simple potential functions for simulating liquid water. The Journal of Chemical Physics, 79(2), 926-935. doi:10.1063/1.445869

Korb, O., Stutzle, T., \& Exner, T. E. (2009). Empirical scoring functions for advanced protein-ligand docking with PLANTS. Journal of Chemical Information and Modeling, 49(1), 84-96. doi:10.1021/ci800298z

MacKerell, A. D., Bashford, D., Bellott, M., Dunbrack, R. L., Evanseck, J. D., Field, M. J., . . . Karplus, M. (1998). All-atom empirical potential for molecular modeling and dynamics 
studies of proteins. The Journal of Physical Chemistry B, 102(18), 3586-3616. doi:10.1021/jp973084f

MacKerell, A. D. Jr., Feig, M., \& Brooks, C. L. 3rd. (2004). Improved treatment of the protein backbone in empirical force fields. Journal of American Chemical Society, 126(3), 698-699. doi:10.1021/ja036959e

Madhosingh, H., \& Southwick, F. S. (2012). Infectious Diseases. In M. P. Harward (Ed.), Medical Secrets (pp. 344-375). Philadelphia: Elsevier Mosby.

Monk, B. C., Tomasiak, T. M., Keniya, M. V., Huschmann, F. U., Tyndall, J. D., O'Connell, J. D., 3rd, . . . Stroud, R. M. (2014). Architecture of a single membrane spanning cytochrome P450 suggests constraints that orient the catalytic domain relative to a bilayer. Proceedings of the National Academy of Sciences of the United States of America, 111(10), 3865-3870. doi:10.1073/pnas.1324245111

Mooij, W. T., \& Verdonk, M. L. (2005). General and targeted statistical potentials for protein-ligand interactions. Proteins, 61(2), 272-287. doi:10.1002/prot.20588

Morio, F., Loge, C., Besse, B., Hennequin, C., \& Le Pape, P. (2010). Screening for amino acid substitutions in the Candida albicans Erg11 protein of azole-susceptible and azoleresistant clinical isolates: new substitutions and a review of the literature. Diagnostic $\begin{array}{llll}\text { Microbiology and Infectious } & \text { 373-384. }\end{array}$ doi:10.1016/j.diagmicrobio.2009.11.006

Morris, G. M., Huey, R., Lindstrom, W., Sanner, M. F., Belew, R. K., Goodsell, D. S., \& Olson, A. J. (2009). AutoDock4 and AutoDockTools4: Automated docking with selective receptor flexibility. Journal of Computational Chemistry, 30(16), 2785-2791. doi:10.1002/jcc.21256

Neises, B., \& Steglich, W. (1978). Simple Method for the Esterification of Carboxylic Acids. Angewandte Chemie International Edition in English, 17(7), 522-524. doi:doi:10.1002/anie.197805221

Ohguro, N., Fukuda, M., Sasabe, T., \& Tano, Y. (1999). Concentration dependent effects of hydrogen peroxide on lens epithelial cells. British Journal of Ophthalmology, 83(9), 1064-1068.

Parker, J. E., Warrilow, A. G., Price, C. L., Mullins, J. G., Kelly, D. E., \& Kelly, S. L. (2014). Resistance to antifungals that target CYP51. Journal of Chemical Biology, 7(4), 143-161. doi:10.1007/s12154-014-0121-1

Phillips, J. C., Braun, R., Wang, W., Gumbart, J., Tajkhorshid, E., Villa, E., . . S Schulten, K. (2005). Scalable molecular dynamics with NAMD. Journal of Computational Chemistry, 26(16), 1781-1802. doi:10.1002/jcc.20289

Polak, E., \& Ribiere, G. (1969). Note sur la convergence de méthodes de directions conjuguées. ESAIM: M2AN, 3(16), 35-43. doi:10.1051/m2an/196903R100351

Porretta, G. C., Fioravanti, R., Biava, M., Cirilli, R., Simonetti, N., Villa, A., . . Tita, B. (1993). Research on antibacterial and antifungal agents. X. Synthesis and antimicrobial activities of 1-phenyl-2-(1H-azol-1-yl) ethane derivatives. Anticonvulsant activity of 1-(4methylphenyl)-2-(1H-imidazol-1-yl) ethanol. European Journal of Medicinal Chemistry, 28(10), 749-760. doi:10.1016/0223-5234(93)90110-Z 
Rupp, B., Raub, S., Marian, C., \& Holtje, H. D. (2005). Molecular design of two sterol 14alpha-demethylase homology models and their interactions with the azole antifungals ketoconazole and bifonazole. Journal of Computer-Aided Molecular Design, 19(3), 149163. doi:10.1007/s10822-005-3692-7

Sari, S., Dalkara, S., Kaynak, F. B., Reynisson, J., Sarac, S., \& Karakurt, A. (2017). New AntiSeizure (Arylalkyl)azole Derivatives: Synthesis, In Vivo and In Silico Studies. Archiv der Pharmazie, 350(6). doi:10.1002/ardp.201700043

Sari, S., Kaynak, F. B., \& Dalkara, S. (2018). Synthesis and anticonvulsant screening of 1,2,4-triazole derivatives. Pharmacological Reports. doi:https://doi.org/10.1016/j.pharep.2018.06.007

Sheng, C., Zhang, W., Zhang, M., Song, Y., Ji, H., Zhu, J., . . . Lu, J. (2004). Homology modeling of lanosterol 14alpha-demethylase of Candida albicans and Aspergillus fumigatus and insights into the enzyme-substrate Interactions. Journal of Biomolecular Structure and Dynamics, 22(1), 91-99. doi:10.1080/07391102.2004.10506984

Silva, S., Rodrigues, C. F., Araujo, D., Rodrigues, M. E., \& Henriques, M. (2017). Candida Species Biofilms' Antifungal Resistance. Journal of Fungi, 3(1). doi:10.3390/jof3010008

Sun, B., Huang, W., \& Liu, M. (2017). Evaluation of the combination mode of azoles antifungal inhibitors with CACYP51 and the influence of Site-directed mutation. Journal of Molecular Graphics and Modelling, 73, 157-165. doi:10.1016/j.jmgm.2017.02.009

Sun, B., Zhang, H., Liu, M., Hou, Z., \& Liu, X. (2018). Structure-based virtual screening and ADME/T-based prediction analysis for the discovery of novel antifungal CYP51 inhibitors. MedChemComm, 9(7), 1178-1187. doi:10.1039/c8md00230d

Thamban Chandrika, N., Shrestha, S. K., Ngo, H. X., Tsodikov, O. V., Howard, K. C., \& Garneau-Tsodikova, S. (2018). Alkylated Piperazines and Piperazine-Azole Hybrids as Antifungal Agents. Journal of Medicinal Chemistry, 61(1), 158-173. doi:10.1021/acs.jmedchem.7b01138

Trott, O., \& Olson, A. J. (2010). AutoDock Vina: improving the speed and accuracy of docking with a new scoring function, efficient optimization, and multithreading. Journal of Computational Chemistry, 31(2), 455-461. doi:10.1002/jcc.21334

Vanommeslaeghe, K., Hatcher, E., Acharya, C., Kundu, S., Zhong, S., Shim, J., . . . Mackerell, A. D., Jr. (2010). CHARMM general force field: A force field for drug-like molecules compatible with the CHARMM all-atom additive biological force fields. Journal of Computational Chemistry, 31(4), 671-690. doi:10.1002/jcc.21367

Verdonk, M. L., Cole, J. C., Hartshorn, M. J., Murray, C. W., \& Taylor, R. D. (2003). Improved protein-ligand docking using GOLD. Proteins, 52(4), 609-623. doi:10.1002/prot.10465

Whaley, S. G., Berkow, E. L., Rybak, J. M., Nishimoto, A. T., Barker, K. S., \& Rogers, P. D. (2016). Azole Antifungal Resistance in Candida albicans and Emerging Non-albicans Candida Species. Frontiers in Microbiology, 7, 2173. doi:10.3389/fmicb.2016.02173

Wong, S. S. W., Samaranayake, L. P., \& Seneviratne, C. J. (2014). In pursuit of the ideal antifungal agent for Candida infections: high-throughput screening of small molecules. Drug Discovery Today, 19(11), 1721-1730. doi:10.1016/j.drudis.2014.06.009 
Wu, J., Ni, T., Chai, X., Wang, T., Wang, H., Chen, J., . . . Jiang, Y. (2018). Molecular docking, design, synthesis and antifungal activity study of novel triazole derivatives. European Journal of Medicinal Chemistry, 143, 1840-1846. doi:10.1016/j.ejmech.2017.10.081

Yates, C. M., Garvey, E. P., Shaver, S. R., Schotzinger, R. J., \& Hoekstra, W. J. (2017). Design and optimization of highly-selective, broad spectrum fungal CYP51 inhibitors. Bioorganic \& Medicinal Chemistry Letters, 27(15), 3243-3248. doi:10.1016/j.bmcl.2017.06.037

Yu, W., He, X., Vanommeslaeghe, K., \& MacKerell, A. D., Jr. (2012). Extension of the CHARMM General Force Field to sulfonyl-containing compounds and its utility in biomolecular simulations. Journal of Computational Chemistry, 33(31), 2451-2468. doi:10.1002/jcc.23067

Zarei Mahmoudabadi, A., Zarrin, M., \& Kiasat, N. (2014). Biofilm Formation and Susceptibility to Amphotericin B and Fluconazole in Candida albicans. Jundishapur Journal of Microbiology, 7(7), e17105. doi:10.5812/jjm.17105

Zhu, F., Logan, G., \& Reynisson, J. (2012). Wine Compounds as a Source for HTS Screening Collections. A Feasibility Study. Molecular Informatics, 31(11-12), 847-855. doi:10.1002/minf.201200103 
Tables

Table 1. The molecular structure of 1-65 azole derivatives.

\begin{tabular}{|c|c|c|c|c|c|c|c|c|c|}
\hline Comp. & $x$ & $Y$ & $Z$ & $\mathrm{R}$ & Comp. & $x$ & $Y$ & $Z$ & $\mathrm{R}$ \\
\hline 1 & $\mathrm{Cl}$ & $\mathrm{CH}$ & $=0$ & - & 34 & $\mathrm{Cl}$ & $\mathrm{N}$ & $=$ NO- & \\
\hline 2 & $\mathrm{Cl}$ & $\mathrm{CH}$ & $=\mathrm{NOH}$ & - & 35 & $\mathrm{Cl}$ & $\mathrm{N}$ & =NO- & \\
\hline 3 & $\mathrm{Cl}$ & $\mathrm{N}$ & $=0$ & - & 36 & $\mathrm{Cl}$ & $\mathrm{N}$ & =NO- & \\
\hline 4 & $\mathrm{Cl}$ & $\mathrm{N}$ & $=\mathrm{NOH}$ & - & 37 & $\mathrm{Cl}$ & $\mathrm{N}$ & $=\mathrm{NO}-$ & \\
\hline 5 & $\mathrm{Cl}$ & $\mathrm{CH}$ & $=\mathrm{NO}-$ & $-\mathrm{CH}_{3}$ & 38 & $\mathrm{H}$ & $\mathrm{N}$ & $-0-$ & $-\mathrm{CH}_{3}$ \\
\hline 6 & $\mathrm{Cl}$ & $\mathrm{CH}$ & =NO- & $\smile \mathrm{CH}_{3}$ & 39 & $\mathrm{H}$ & $\mathrm{N}$ & $-0-$ & \\
\hline 7 & $\mathrm{Cl}$ & $\mathrm{CH}$ & $=\mathrm{NO}-$ & ${\widehat{\mathrm{CH}_{3}}}$ & 40 & $\mathrm{H}$ & $\mathrm{N}$ & $-0-$ & \\
\hline 8 & $\mathrm{Cl}$ & $\mathrm{CH}$ & $=\mathrm{NO}-$ & $\mathrm{CH}_{3}$ & 41 & $\mathrm{H}$ & $\mathrm{N}$ & $-0-$ & \\
\hline 9 & $\mathrm{Cl}$ & $\mathrm{CH}$ & $=\mathrm{NO}-$ & & 42 & $\mathrm{H}$ & $N$ & $-0-$ & \\
\hline 10 & $\mathrm{Cl}$ & $\mathrm{CH}$ & $=\mathrm{NO}-$ & & 43 & $\mathrm{H}$ & $\mathrm{N}$ & -0 & \\
\hline 11 & $\mathrm{Cl}$ & $\mathrm{CH}$ & $=\mathrm{NO}-$ & & 44 & $\mathrm{H}$ & $N$ & -0 & \\
\hline 12 & $\mathrm{Cl}$ & $\mathrm{CH}$ & $=\mathrm{NO}-$ & & 45 & $\mathrm{H}$ & $N$ & $-0-$ & \\
\hline 13 & $\mathrm{Cl}$ & $\mathrm{CH}$ & $=\mathrm{NO}-$ & & 46 & $\mathrm{H}$ & $\mathrm{N}$ & $-0-$ & \\
\hline 14 & $\mathrm{Cl}$ & $\mathrm{CH}$ & $=\mathrm{NO}-$ & & 47 & $\mathrm{H}$ & $\mathrm{N}$ & $-0-$ & \\
\hline 15 & $\mathrm{Cl}$ & $\mathrm{CH}$ & $=\mathrm{NO}-$ & & 48 & $\mathrm{H}$ & $N$ & -0 & \\
\hline 16 & $\mathrm{Cl}$ & $\mathrm{CH}$ & $=\mathrm{NO}-$ & & 49 & $\mathrm{H}$ & $N$ & -0 & \\
\hline 17 & $\mathrm{Cl}$ & $\mathrm{CH}$ & $=\mathrm{NO}-$ & & 50 & $\mathrm{H}$ & $N$ & -0 & \\
\hline 18 & $\mathrm{Cl}$ & $\mathrm{CH}$ & $=\mathrm{NO}-$ & & 51 & $\mathrm{H}$ & $N$ & -0 & \\
\hline 19 & $\mathrm{Cl}$ & $\mathrm{CH}$ & $=\mathrm{NO}-$ & & 52 & $\mathrm{Cl}$ & $N$ & $-0-$ & $-\mathrm{CH}_{3}$ \\
\hline 20 & $\mathrm{Cl}$ & $\mathrm{CH}$ & $=\mathrm{NO}-$ & & 53 & $\mathrm{Cl}$ & $\mathrm{N}$ & -0 & \\
\hline 21 & $\mathrm{Cl}$ & $\mathrm{CH}$ & $=\mathrm{NO}-$ & & 54 & $\mathrm{Cl}$ & $N$ & -0 & \\
\hline 22 & $\mathrm{Cl}$ & $\mathrm{N}$ & $=\mathrm{NO}-$ & & 55 & $\mathrm{Cl}$ & $N$ & -0 & \\
\hline 23 & $\mathrm{Cl}$ & $\mathrm{N}$ & $=\mathrm{NO}-$ & $\mathrm{CH}_{3}$ & 56 & $\mathrm{Cl}$ & $N$ & -0 & \\
\hline 24 & $\mathrm{Cl}$ & $\mathrm{N}$ & $=\mathrm{NO}-$ & $\mathrm{CH}_{3}$ & 57 & $\mathrm{Cl}$ & $N$ & -0 & \\
\hline 25 & $\mathrm{Cl}$ & $\mathrm{N}$ & $=\mathrm{NO}-$ & & 58 & $\mathrm{Cl}$ & $N$ & $-0-$ & \\
\hline
\end{tabular}




$\begin{array}{llllllll}26 & \mathrm{Cl} & \mathrm{N} & =\mathrm{NO}- \\ 27 & \mathrm{Cl} & \mathrm{N} & =\mathrm{NO}- \\ 28 & \mathrm{Cl} & \mathrm{N} & =\mathrm{NO}- \\ 29 & \mathrm{Cl} & \mathrm{N} & =\mathrm{NO}- \\ 30 & \mathrm{Cl} & \mathrm{N} & =\mathrm{NO}- \\ 31 & \mathrm{Cl} & \mathrm{N} & =\mathrm{NO}- \\ 32 & \mathrm{Cl} & \mathrm{N} & =\mathrm{NO}- \\ 33 & \mathrm{Cl} & \mathrm{N} & =\mathrm{NO}-\end{array}$


Table 2. MIC values ( $\mu \mathrm{g} / \mathrm{ml})$ of 1-65 against standard cultures of Candida spp. and azoleresistant $C$. tropicalis isolate.

\begin{tabular}{|c|c|c|c|c|}
\hline Compound & $\begin{array}{l}\text { C. albicans } \\
\text { ATCC } 90028\end{array}$ & $\begin{array}{c}\text { C. krusei } \\
\text { ATCC } 6258\end{array}$ & $\begin{array}{l}\text { C. parapsilosis } \\
\text { ATCC } 90018\end{array}$ & $\begin{array}{c}\text { C. tropicalis } \\
\text { (resistant isolate) }\end{array}$ \\
\hline 1 & 128 & 256 & 64 & 256 \\
\hline 2 & 128 & 64 & 32 & 512 \\
\hline 3 & 128 & 256 & 128 & 256 \\
\hline 4 & 512 & 512 & 256 & 512 \\
\hline 5 & 128 & 256 & 128 & - \\
\hline 6 & 128 & 256 & 128 & - \\
\hline 7 & 128 & 256 & 64 & - \\
\hline 8 & 32 & 64 & 16 & 256 \\
\hline 9 & 16 & 64 & 16 & 256 \\
\hline 10 & 64 & 128 & 64 & - \\
\hline 11 & 32 & 32 & 32 & 512 \\
\hline 12 & 2 & 64 & 2 & 256 \\
\hline 13 & 0.25 & 16 & 0.25 & 256 \\
\hline 14 & 128 & 256 & 128 & 256 \\
\hline 15 & 32 & 128 & 16 & 256 \\
\hline 16 & 128 & 256 & 256 & - \\
\hline 17 & 128 & 256 & 128 & - \\
\hline 18 & 256 & 128 & 256 & - \\
\hline 19 & 128 & 256 & 128 & - \\
\hline 20 & 64 & 128 & 8 & - \\
\hline 21 & 128 & 256 & 256 & - \\
\hline 22 & 256 & 256 & 128 & - \\
\hline 23 & 256 & 256 & 128 & - \\
\hline 24 & 64 & 128 & 32 & - \\
\hline 25 & 256 & 512 & 512 & - \\
\hline 26 & 128 & 256 & 128 & - \\
\hline 27 & 128 & 256 & 128 & - \\
\hline 28 & 256 & 256 & 128 & - \\
\hline 29 & 256 & 128 & 128 & - \\
\hline 30 & 128 & 128 & 128 & - \\
\hline 31 & 512 & 128 & 512 & - \\
\hline 32 & 16 & 128 & 16 & 512 \\
\hline 33 & 256 & 128 & 64 & - \\
\hline 34 & 16 & 256 & 16 & 256 \\
\hline 35 & 256 & 256 & 128 & - \\
\hline 36 & 256 & 256 & 16 & - \\
\hline 37 & 128 & 128 & 256 & - \\
\hline 38 & 128 & 256 & 128 & - \\
\hline 39 & 256 & 256 & 256 & - \\
\hline 40 & 256 & 512 & 256 & - \\
\hline 41 & 256 & 256 & 256 & - \\
\hline 42 & 256 & 256 & 256 & - \\
\hline
\end{tabular}




\begin{tabular}{ccccc}
$\mathbf{4 3}$ & 256 & 256 & 256 & - \\
$\mathbf{4 4}$ & 256 & 256 & 256 & - \\
$\mathbf{4 5}$ & 128 & 256 & 256 & - \\
$\mathbf{4 6}$ & 256 & 256 & 256 & - \\
$\mathbf{4 7}$ & 256 & 256 & 256 & - \\
$\mathbf{4 8}$ & 256 & 256 & 256 & - \\
$\mathbf{4 9}$ & 256 & 256 & 256 & - \\
$\mathbf{5 0}$ & 256 & 256 & 256 & - \\
$\mathbf{5 1}$ & 256 & 512 & 256 & - \\
$\mathbf{5 2}$ & 128 & 256 & 128 & - \\
$\mathbf{5 3}$ & 256 & 256 & 256 & - \\
$\mathbf{5 4}$ & 128 & 256 & 128 & - \\
$\mathbf{5 5}$ & 128 & 128 & 256 & - \\
$\mathbf{5 6}$ & 128 & 128 & 256 & - \\
$\mathbf{5 7}$ & 256 & 256 & 256 & - \\
$\mathbf{5 8}$ & 128 & 256 & 128 & - \\
$\mathbf{5 9}$ & 128 & 256 & 128 & - \\
$\mathbf{6 0}$ & 512 & 256 & 512 & - \\
$\mathbf{6 1}$ & 128 & 256 & 128 & - \\
$\mathbf{6 2}$ & 128 & 128 & 128 & - \\
$\mathbf{6 3}$ & 128 & 128 & 128 & - \\
$\mathbf{6 4}$ & 128 & 256 & 128 & 512 \\
$\mathbf{6 5}$ & 128 & 256 & 128 & - \\
Fluconazole & 0.5 & 32 & 0.5 & \\
\hline
\end{tabular}

Table 3. The minimum biofilm inhibitor and eradicator concentration (MBIC and MBEC) values $(\mu \mathrm{g} / \mathrm{ml})$ of 12 and 13.

\begin{tabular}{ccc}
\hline Compound & MBIC & MBEC \\
\hline 12 & 2 & 256 \\
13 & 0.5 & 512 \\
Amphotericin B & 4 & 256 \\
\hline
\end{tabular}


Table 4. Some of the calculated molecular descriptors/properties for $\mathbf{1 2}$ and 13.

\begin{tabular}{|c|c|c|c|}
\hline \multicolumn{2}{|c|}{ Property/descriptor and its definition } & \multirow{2}{*}{$\begin{array}{c}12 \\
8\end{array}$} & \multirow{2}{*}{$\begin{array}{c}13 \\
6\end{array}$} \\
\hline RB & Number of non-trivial, non-hindered rotatable bonds. & & \\
\hline MW & molecular weight (g/mol) & 329.8 & 339.8 \\
\hline HD & $\begin{array}{l}\text { Estimated number of hydrogen bonds that would be } \\
\text { donated by the solute to water molecules in an } \\
\text { aqueous solution. }\end{array}$ & 0 & 0 \\
\hline $\mathrm{HA}$ & $\begin{array}{l}\text { Estimated number of hydrogen bonds that would be } \\
\text { accepted by the solute from water molecules in an } \\
\text { aqueous solution. }\end{array}$ & 5.5 & 5.5 \\
\hline Log $\mathrm{P}$ & Predicted octanol/water partition coefficient. & 3.8 & 3.6 \\
\hline PSA & $\begin{array}{l}\text { Van der Waals surface area of polar nitrogen and } \\
\text { oxygen } \\
\text { atoms and carbonyl carbon atoms. }\end{array}$ & 62.0 & 60.6 \\
\hline
\end{tabular}

Table 5. RMSD values $(\AA ̊)$ of ITR docked to CACYP51 catalytic site regarding its original conformer and docking scores of ITR for each software/algorithm.

\begin{tabular}{cccccccc}
\hline & \multicolumn{5}{c}{ GOLD } & & \\
\cline { 2 - 5 } & GS & CS & ASP & ChemPLP & Autodock & AutoDock Vina & Glide $^{\mathrm{a}}$ \\
\hline RMSD (Å) & 1.48 & 1.62 & 3.36 & 1.43 & 1.43 & 1.67 & 2.25 \\
Docking score $^{\mathrm{b}}$ & 99.2 & 59.2 & 66.1 & 111.4 & -14.0 & -10.0 & -7.4 \\
\hline${ }^{\mathrm{a}}$ Standard precision mode \\
${ }^{\mathrm{b}}$ Fitness score for GOLD (dimensionless), free energy of binding (kcal/mol) for AutoDock and AutoDock \\
Vina, and Glide score (kcal/mol) for Glide.
\end{tabular}

Table 6. Docking scores of 12 and 13.

\begin{tabular}{cccccccc}
\hline & \multicolumn{4}{c}{ GOLD fitness scores } & \multicolumn{2}{c}{$\begin{array}{c}\text { Free energy of binding } \\
\text { (kcal/mol) }\end{array}$} & $\begin{array}{c}\text { Glide score } \\
\text { Comp. }\end{array}$ \\
\cline { 2 - 5 } & GS & CS & ASP & ChemPLP & Autodock & AutoDock Vina & (kcal/mol) \\
\hline $\mathbf{1 2}$ & 66.1 & 34.8 & 42.3 & 78.8 & -7.9 & -8.2 & -7.3 \\
13 & 65.1 & 34.0 & 44.9 & 81.7 & -8.1 & -8.5 & -7.3 \\
\hline
\end{tabular}


Table 7. Distances $(\AA)$ between the heme-coordinating $N$ of the imidazole of $\mathbf{1 2}$ and $\mathbf{1 3}$ and the heme $\mathrm{Fe}^{2+}$.

\begin{tabular}{cccccccc}
\hline & \multicolumn{5}{c}{ GOLD } & & \\
$n_{$\cline { 2 - 5 } \text {$Compound }^{\mathrm{a}}}$ & GS & CS & ASP & ChemPLP & Autodock & AutoDock Vina & Glide \\
\hline $\mathbf{1 2}$ & 2.01 & 3.57 & 2.77 & 3.15 & 2.02 & 2.85 & 3.61 \\
$\mathbf{1 3}$ & 2.13 & 3.62 & 3.02 & 3.59 & 1.96 & 3.83 & 3.67 \\
\hline
\end{tabular}

${ }^{\mathrm{a}}$ This value is $2.54 \AA$ for ITR present in the homology model

Table 8. RMS fluctuations $(\AA)$ of the CACYP51 residues interacting with 13 in apo and 13bound states.

\begin{tabular}{ccccccccc}
\hline Residue $^{\mathrm{a}}$ & Apo & 13-bound & RMSF gap & & Residue $^{\mathrm{a}}$ & Apo & 13-bound & RMSF gap \\
\cline { 1 - 3 } \cline { 6 - 8 } 118 & 1.28 & 0.84 & 0.43 & & $\mathbf{3 0 7}$ & 2.65 & 1.17 & 1.48 \\
$\mathbf{1 2 1}$ & 3.44 & 1.23 & 2.21 & & 308 & 1.86 & 1.03 & 0.83 \\
122 & 1.90 & 0.83 & 1.08 & & 311 & 1.70 & 1.08 & 0.62 \\
126 & 2.10 & 1.13 & 0.98 & & $\mathbf{3 7 6}$ & 2.78 & 1.36 & 1.42 \\
131 & 1.60 & 1.24 & 0.36 & & 377 & 1.64 & 2.02 & -0.37 \\
$\mathbf{2 2 8}$ & 4.09 & 1.57 & 2.53 & & 378 & 1.35 & 1.96 & -0.62 \\
303 & 2.20 & 0.94 & 1.26 & & 380 & 2.32 & 1.71 & 0.62 \\
$\mathbf{3 0 4}$ & 2.49 & 1.12 & 1.36 & & $\mathbf{5 0 8}$ & 4.64 & 2.89 & 1.74 \\
306 & 2.31 & 1.30 & 1.01 & & 509 & 2.08 & 1.91 & 0.17 \\
\hline
\end{tabular}

${ }^{\text {a }}$ Residues with the highest RMSF gap are highlighted as bold. 


\section{FIGURE LEGENDS}

Scheme 1. Synthesis of derivatives 17, 18, and 37.

Figure 1. The effect of 12 (A) and 13 (B) on cell viability of L929 cells for $48 \mathrm{~h}$.

Figure 2. Binding modes of 13 (orange sticks) in CACYP51 catalytic site obtained from molecular docking and the original conformer of ITR (green sticks). Molecular surface of the protein is rendered.

Figure 3. Superimposition of the binding modes of 12 and 13 in CACYP51 catalytic site obtained from GOLD GS (A), 2D interaction diagram of 13- and 12-CACYP51 complexes (B and C) from GOLD GS.

Figure 4. Plots showing apo and 13-bound CACYP51's Ca RMSD values (A) over time and average RMS fluctuations of each residue (B).
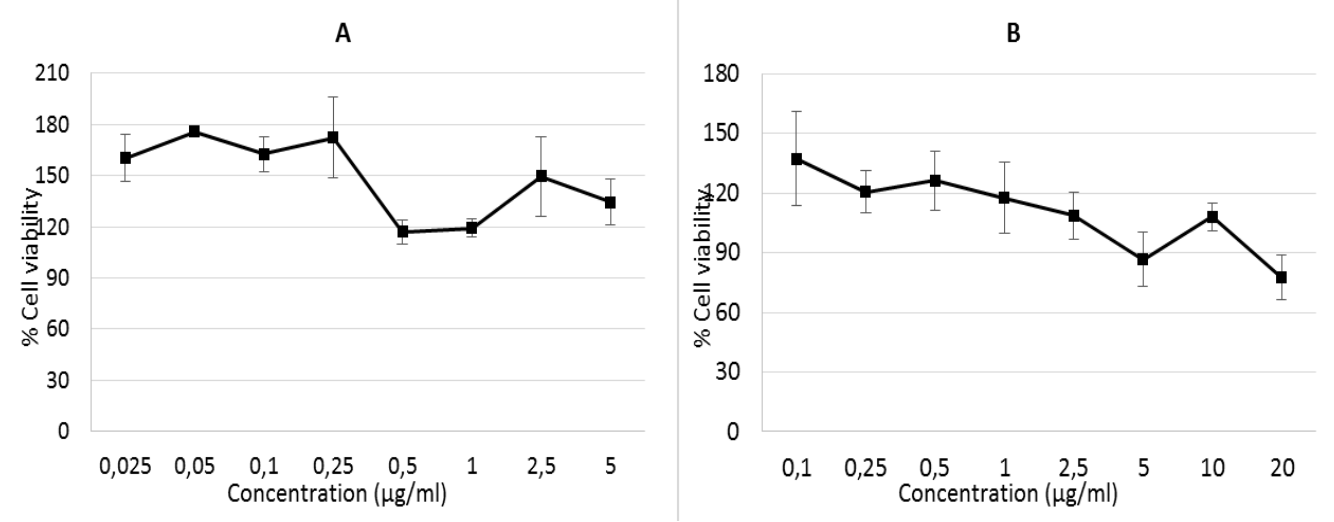

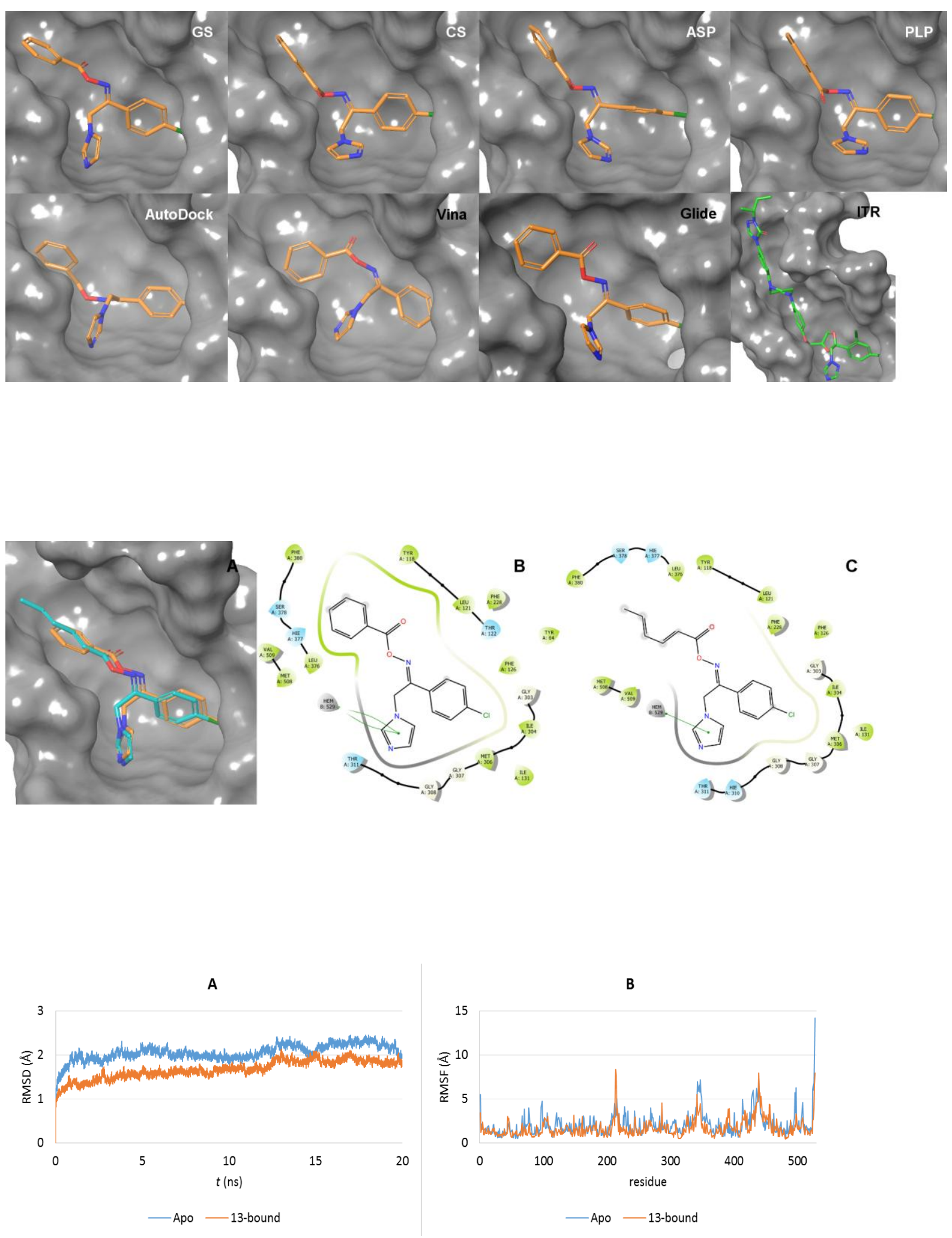

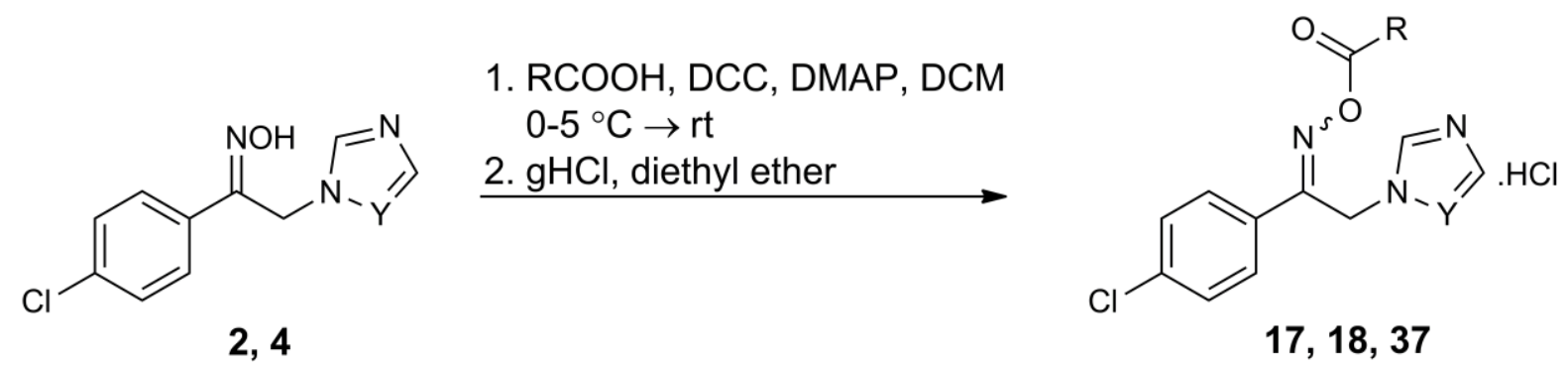

Y: $\mathrm{CH}(2,17,18) ; \mathrm{N}(4,37)$

R:<smiles>Cc1ccc(Cl)cc1</smiles>

17<smiles>Cc1ccc(Cl)cc1Cl</smiles>

18
$17,18,37$<smiles>Cc1ccc(-c2ccccc2)cc1</smiles>

37 